\title{
PREDIKSI KUALITAS AIR BERSIH PDAM KOTA PALU MENGGUNAKAN METODE BACKPROPAGATION
}

\author{
J.R. Mustakim ${ }^{1}$, R. Ratianingsih ${ }^{2}$ dan D. Lusiyanti ${ }^{3}$ \\ 1,2,3 Program Studi Matematika Jurusan Matematika FMIPA Universitas Tadulako \\ Jalan Soekarno-Hatta Km. 09 Tondo, Palu 94118, Indonesia. \\ 1jrmustakim.sanz20@gmail.com,2ratianingsih@yahoo.com, 3Desylusiyanti@yahoo.com
}

\begin{abstract}
Artificial neural network is a computing system architecture and operation inspired by the knowledge of the biological nerve cells in the brain. Artificial neural network is one of the artificial representation of the human brain that always trying to simulate the learning process of the human brain. The purpose of this study is to develop a neural network of the water quality prediction. The study was conducted by using the monthly parameters of water quality, namely odor, color, turbidity, taste, temperature, bacteria $\mathrm{E}$ Coli, $\mathrm{pH}$, and residual chlorine in PDAM Palu from January 2012 - December 2015. There are 48 used trainingdata to be processed by backpropagation, which is one of algorithm often used to deal with complex issues and complex. This study consists of three layers. The first one is the input parameters of water quality parameters such as clean, odor, color, turbidity, taste, temperature, bacteria $\mathrm{E}$ Coli, $\mathrm{pH}$, and residual chlorine which consists of eight variables. The hidden layer comprising of 12 neurons and one output layer.The training process showes a maximum result at 1000 iteration, constant learning 0.5 and 0.1 momentum and the level of accuracy of $91.67 \%$. The water quality prediction for 2016 in PDAM Kota Palu are not clean (1) on Januari , clean (0) on February, not clean (1) on March, clean (0) on April, clean (0) on Mei, not clean (1) on Juni, clean (0) on Juli, clean (0) on August, clean (0) on September, clean (0) on October, not clean (1) on November, and clean (0) on December.
\end{abstract}

Keywords : : Accuracy, Backpropagation, Neural Network, Prediction, Water Quality.

\section{ABSTRAK}

jaringan syaraf tiruan adalah arsitektur sistem komputasi dan operasi terinspirasi oleh pengetahuan tentang selsel saraf biologis dalam otak. jaringan syaraf tiruan merupakan salah satu representasi buatan dari otak manusia yang selalu mencoba untuk mensimulasikan proses pembelajaran pada otak manusia. Tujuan dari penelitian ini adalah untuk mengembangkan jaringan saraf dari prediksi kualitas air. Penelitian dilakukan dengan menggunakan parameter bulanan kualitas air, yaitu bau, warna, kekeruhan, rasa, suhu, bakteri $\mathrm{E}$ Coli, $\mathrm{pH}$, dan sisa chlor di PDAM Palu dari Januari 2012 - Desember 2015. Ada 48 data menggunakan data pelatihan untuk diproses oleh backpropagation, yang merupakan salah satu algoritma yang sering digunakan untuk menangani masalah yang kompleks dan rumit. Penelitian ini terdiri dari tiga lapisan. Yang pertama adalah parameter masukan dari parameter kualitas air seperti bersih, bau, warna, kekeruhan, rasa, suhu, bakteri E Coli, pH, dan sisa khlor yang terdiri dari delapan variabel. Tersembunyi lapisan yang terdiri dari 12 neuron dan satu lapisan keluar. Dari proses pelatihan didapatkan hasil maksimal pada 1000 iterasi, konstanta belajar 0,5 dan 0,1 momentum dan tingkat akurasi 91,67\%. Prediksi kualitas air untuk 2016 di PDAM Kota Palu adalah Januari $=1$ (tidak bersih), Februari $=0$ (bersih), Maret $=1$ (tidak bersih), April = 0 (bersih), Mei = 0 (bersih), Juni = 1 (bersih), 
Juli $=0$ (bersih), Agustus $=0$ (bersih), September $=0$ (bersih), Oktober $=0$ (bersih), November $=1$ (tidak bersih), dan Desember $=0$ (bersih).

Kata Kunci : Akurasi, Backpropagation, Jaringan Syaraf Tiruan, Kualitas Air Bersih, Prediksi.

\section{LATAR BELAKANG}

\subsection{Latar Belakang}

Air merupakan kebutuhan yang sangat penting bagi kehidupan makhluk hidup. Keberlangsungan makhluk hidup di bumi tergantung pada keseterdiaan air. Air bersih merupakan komponen utama aktivitas manusia, baik untuk air minum, kebutuhan rumah tangga serta aktivitas pendukung lainnya. Karena pentingnya air bagi kehidupan manusia, pemerintah menjamin kebutuhan air warga negaranya seperti yang tertuang dalam pasal 5 BAB I Undang-undang Republik Indonesia No. 7 tahun 2004, yang berbunyi : "Negara menjamin hak setiap orang untuk mendapatkan air bagi kebutuhan pokok minimal sehari-hari guna memenuhi kebutuhannya yang sehat, bersih dan produktif. Mengingat air bersih merupakan salah satu parameter penting dalam kesehatan lingkungan, pada penelitian ini penulis tertarik untuk meneliti kualitas air PDAM Kota Palu. Setiap hari manusia membutuhkan air bersih untuk minum, memasak, mandi, mencuci dan sebagainya. Dengan air yang bersih, manusia dapat melakukan protentif untuk terhindar dari penyakit. Mengingat air bersih mudah terkontaminasi polusi air dan udara sehingga mempengaruhi rasa maupun warna. Pengukuran kualitas air memerlukan pengujian terhadap beberapa parameterparameter tingkat kualitas air. Parameter-parameter tersebut adalah parameter fisik, parameter mikrobiologi, parameter kimia dan parameter lainnya seperti sisa khlor. Setiap parameter akan membangun suatu model yang dapat dipakai untuk mengukur kualitas air bersih.

Jaringan syaraf tiruan (JST) dapat digunakan untuk membangun model kualitas air PDAM yang di ukur dari pemenuhan nilai parameter-parameter pembangunnya. Sistem pemrosesan informasi dalam JST didesain dengan menirukan cara kerja otak manusia dalam menyelesaikan suatu masalah dengan melakukan proses belajar melalui perubahan bobot sinapsisnya. JST mampu mengenali data berbasis pada data yang ada pada masa lampau. Data masa lampau tersebut akan dipelajari oleh JST sehingga mempunyai kemampuan untuk memberi keputusan terhadap data yang belum pernah dipelajari (Hermawan, 2006). Setiap parameter memiliki standar yang dipakai sedemikian hingga kualitas air dapat dikategorikan kualitasnya. Apabila parameter-parameter penentu kualitas air berada dalam interval yang telah ditentukan maka kualitas air dikategorikan baik. Kualitas air PDAM Kota Palu digolongkan dalam 2 kategori, yaitu baik dan tidak baik. Jika nilai suatu parameter tidak memenuhi standar yang ditentukan maka air dikatakan tidak baik.Salah satu metode JST 
yang dapat digunakan membangun model kualitas air PDAM Kota Palu adalah Backpropagation. Metode tersebut sering digunakan karena kemampuan generalisasi yang cukup baik untuk masalah prediksi. Keunggulan dari metode ini adalah kemampuannya menurunkan gradien untuk meminimalkan jumlah kuadrat error dari output jaringan (Puspitaningrum, 2006). Keunggulan tersebut akan memberikan jaminan akurasi prediksi kualitas air yang dihasilkannya.

\subsection{Rumusan Masalah}

Bagaimana prediksi kualitas air PDAM Kota Palu dalam tahun 2016 menggunakan metode backpropagation?

\subsection{Tujuan Penelitian}

Tujuan penelitian ini adalah untuk mendapatkan hasil prediksi kualitas air bersih PDAM Kota Palu dalam tahun 2016 dengan menggunakan metode backpropagation.

\subsection{Batasan Masalah}

Data yang digunakan dalam penelitian ini adalah data bulanan pengukuran parameter kualitas air PDAM Kota Palu dari tahun 2012 - 2015.

\subsection{Manfaat Penelitian}

Manfaat yang dapat diambil dari penelitian ini adalah :

1. Memperkaya literatur dalam bidang JST terlebih khusus dengan menggunakan algoritma pembelajaran backpropagation.

2. Sebagai dasar atau pedoman untuk pengembangan sistem prediksi pada pada kasus - kasus lainnya.

\section{METODE PENELITIAN}

Penelitian ini dilakukan sesuai dengan prosedur dibawah ini :

1. Melakukan studi literatur

2. Menganalisa Masalah

3. Mengumpulkan beberapa data dari berbagai sumber yang ada

4. Penerapan metode backpropagation pada pola pengenalan dan membuat programnya

5. Melakukan proses training dan testing pada data

6. Setelah hasil dari contoh kasus diperoleh kemudian akan diberi penjelasan atas hasil yang di dapat kemudian disimpulkan. 


\section{HASIL DAN PEMBAHASAN}

\subsection{Pengumpulan Data}

Data penelitian ini diambil dari kantor PDAM Kota Palu. Data tersebut terdiri dari 8 parameter untuk mengukur kualitas air bersih, yaitu Bau, warna, kekeruhan, rasa, suhu, bakteri $\mathrm{E}$ Coli, $\mathrm{pH}$, dan sisa chlor.

Data 8 parameter kualitas air bersih tersebut sebanyak 48 data yang diambil dari tahun 2012 - 2015. Data dibagi ke dalam dua bagian, satu bagian digunakan untuk proses testing dan satu bagian digunakan untuk data training. Data training digunakan untuk membangun model, sedangkan data testing digunakan untuk mengukur akurasi model. Prediksi kualitas air ini menggunakan $80 \%$ untuk data training dan $20 \%$ untuk data testing. Maka dari itu data training pada peramalan ini terdiri dari 36 data dan data testing terdiri dari 12 data.

\subsection{Normalisasi Data}

Normalisasi / scaling (perubahan rentang dari nilai atribut) atribut bernilai bilangan real umumnya juga diperlukan agar proses perhitungan lebih mudah dan memberi jaminan bahwa atribut yang rentang nilainya lebih kecil. Normalisasi umumnya memberikan hasil yang lebih baik. Rentang nilai atribut yang dianjurkan untuk digunakan adalah $[0,1]$ atau $[-1,+1](\mathrm{Hsu}, \mathrm{C}$, W, 2004).

Normalisasi dalam rentang nilai $[0,1]$ menghasilkan akurasi yang sama dengan $[-1,+1]$, tetapi waktu komputasi yang dibutuhkan mungkin berbeda (Sembiring, K, 2007). Normalisasi yang dilakukan pada training data, harus dilakukan juga dengan cara yang sama terhadap testing data. Adapun rumus normalisasi pada program matlab sebagai berikut :

$$
\text { Xnew }=(x-\text { ones }(R, 1) * \text { mean }(x)) . /(\text { ones }(48,1) * \operatorname{std}(x))
$$

Tabel 1 : Hasil Normalisasi Data

\begin{tabular}{|c|c|c|c|c|c|c|c|c|c|}
\hline Pola & $x_{1}$ & $x_{2}$ & $x_{3}$ & $x_{4}$ & $x_{5}$ & $x_{6}$ & $x_{7}$ & $x_{8}$ & $t$ \\
\hline 1 & 1 & 1 & 1 & 1 & $-0,12$ & 4,94 & 0,38 & $-0,15$ & 0 \\
\hline 2 & 1 & 1 & 1 & 1 & $-0,12$ & $-0,14$ & 0,38 & 1,43 & 0 \\
\hline 3 & 1 & 1 & 1 & 1 & $-0,12$ & $-0,53$ & 0,90 & 1,43 & 1 \\
\hline 4 & 1 & 1 & 1 & 1 & $-0,12$ & 0,45 & $-0,66$ & $-0,15$ & 0 \\
\hline 5 & 1 & 1 & 1 & 1 & $-0,12$ & 0,64 & $-0,14$ & $-0,15$ & 1 \\
\hline 6 & 1 & 1 & 1 & 1 & $-0,12$ & $-0,53$ & $-0,14$ & $-0,15$ & 1 \\
\hline 7 & 1 & 1 & 1 & 1 & $-0,12$ & $-0,53$ & $-0,14$ & $-0,15$ & 1 \\
\hline 8 & 1 & 1 & 1 & 1 & $-0,12$ & $-0,53$ & $-1,70$ & $-2,80$ & 1 \\
\hline
\end{tabular}




\begin{tabular}{|c|c|c|c|c|c|c|c|c|c|}
\hline 9 & 1 & 1 & 1 & 1 & $-0,12$ & $-0,53$ & $-1,18$ & $-0,15$ & 1 \\
\hline 10 & 1 & 1 & 1 & 1 & $-0,12$ & $-0,53$ & 1,94 & $-0,15$ & 1 \\
\hline 11 & 1 & 1 & 1 & 1 & $-0,12$ & $-0,53$ & $-1,18$ & $-0,15$ & 1 \\
\hline 12 & 1 & 1 & 1 & 1 & $-2,94$ & 0,45 & $-0,14$ & $-0,15$ & 0 \\
\hline$\vdots$ & $\vdots$ & $\vdots$ & $\vdots$ & $\vdots$ & $\vdots$ & $\vdots$ & $\vdots$ & $\vdots$ & $\vdots$ \\
\hline 48 & 1 & 1 & 1 & 1 & $-0,12$ & $-0,53$ & $-0,66$ & $-0,15$ & 0 \\
\hline
\end{tabular}

\subsection{Pembentukan Arsitektur Jaringan}

Dalam membentuk arsitektur jaringan syaraf tiruan dibentuk pola-pola hubungan antara neuron. Neuron-neuron tersebut akan mentransformasikan informasi yang diterima melalui sambungan keluarnya menuju ke neuron-neuron yang lain. Pada jaringan syaraf hubungan ini dikenal dengan nama bobot dan bias. Adapun arsitektur jaringan yang digunakan dalam penelitian ini adalah sebagai berikut :

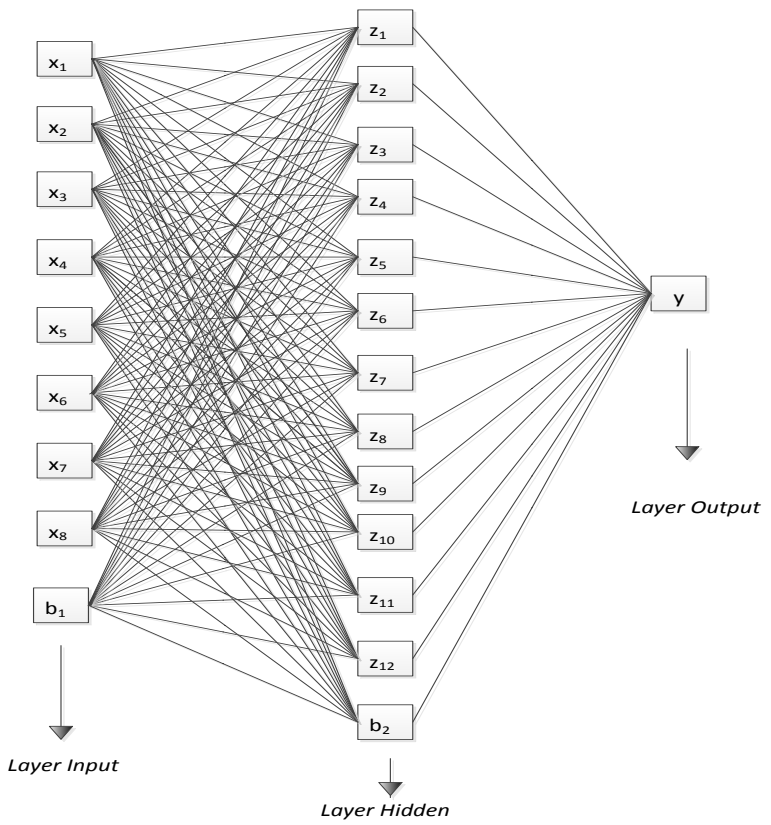

Gambar 1 : Arsitektur Jaringan Syaraf Tiruan

\subsection{Pengolahan Data Menggunakan Program Matlab dengan Metode Backpropagation}

\section{a. Pelatihan data (Training)}

Data pelatihan ini merupakan data yang digunakan untuk membangun dan melatih sistem JST yang telah dibuat, dimana pada data pelatihan ini telah ditetapkan nilai target yang ingin dihasilkan, sehingga jika hasil yang diperoleh pada pelatihan tidak sesuai dengan target, maka akan dilakukan perbaikan pada sistem JST tersebut. 
Uji coba yang dilakukan menggunakan data training berukuran 36x8. 36 adalah jumlah data dan 8 adalah faktor parameter kualitas air bersih yang dijadikan sebagai atribut untuk dapat memprediksi kualitas air bersih. Proses training dapat ditampilkan pada gambar berikut.

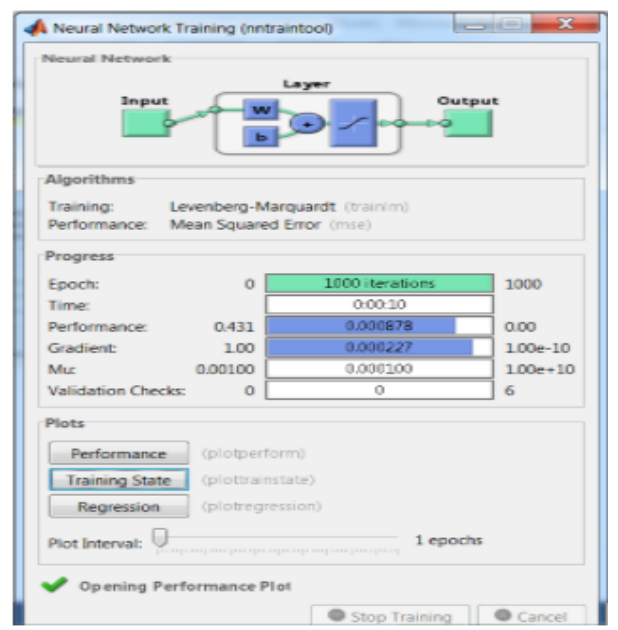

Gambar 2: Proses pelatihan data pada matlab 2010

Keberhasilan proses training diperlihatkan di performance yang ditampilkan pada Gambar 3. Gambar tersebut memperlihatkan hasil grafik MSE yang terjadi pada proses pelatihan.

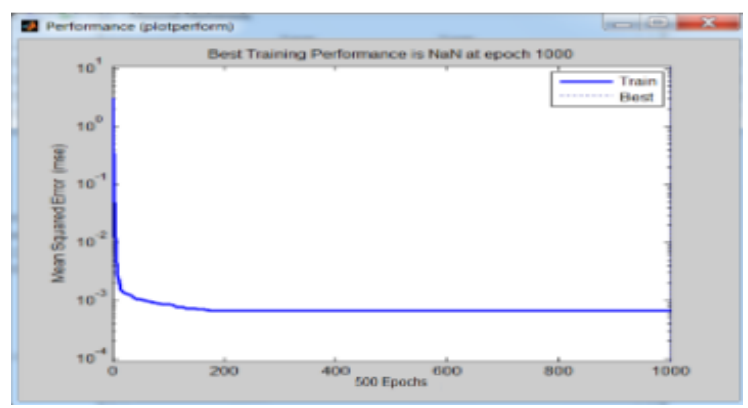

Gambar 3 : Performance

Selanjutnya pada Gambar 4 memperlihatkan hasil dari pelatihan data yang menghasilkan yt dimana yt adalah hasil prediksi. 


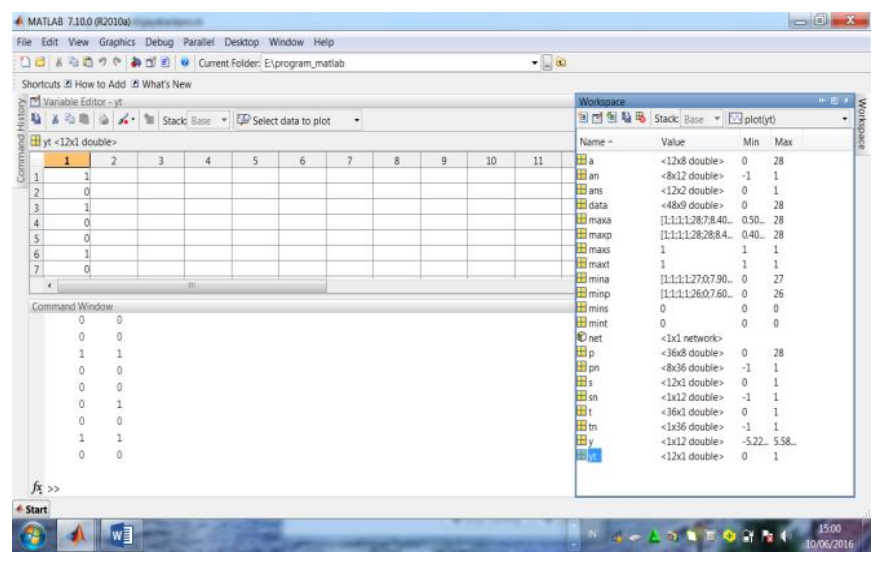

Gambar 4 : Hasil Prediksi dari Pelatihan Data

\section{b. Pengujian Data (testing)}

Pengujian data merupakan tahapan dimana sistem mulai melakukan proses prediksi harga komoditi pangan. Input data yang akan diuji adalah yang memiliki faktor harga yang sama dengan data pelatihan. Pengujian data menggunakan 12 data untuk 1 kualitas air. Pengujian dilakukan menggunakan rancangan arsitektur terbaik yang telah diperoleh dari hasil pelatihan, struktur jaringan yang digunakan terdiri dari satu lapis yang berisi 8 neuron input. Lapisan tersembunyi pertama terdiri dari 12 neuron dan lapisan output terdiri dari 1 neuron.

Tabel 2 : Hasil perbandingan prediksi dan data aktual untuk kualitas air

\begin{tabular}{|c|c|c|}
\hline Bulan & Prediksi & Data Aktual dari Kantor PDAM Kota Palu \\
\hline Januari & 1 & 1 \\
\hline Februari & 0 & 0 \\
\hline Maret & 1 & 1 \\
\hline April & 0 & 0 \\
\hline Mei & 0 & 0 \\
\hline Juni & 1 & 1 \\
\hline Juli & 0 & 0 \\
\hline Agustus & 0 & 0 \\
\hline September & 0 & 1 \\
\hline Oktober & 0 & 0 \\
\hline November & 1 & 1 \\
\hline Desember & 0 & 0 \\
\hline
\end{tabular}


Perbandingan hasil prediksi dan data aktual juga ditampilkan pula dalam Gambar 6. Dari Tabel 2 dapat dilihat tingkat keakurasian yang dicapai :

Akurasi data yang sesuai target :

$$
\begin{gathered}
=\frac{\text { Jumlah data yang benar diprediksi }}{\text { jumlah data }} \times 100 \% \\
=\frac{11}{12} \times 100 \% \\
=91,67 \%
\end{gathered}
$$

Akurasi data yang tidak sesuai target

$$
\begin{gathered}
=\frac{\text { Jumlah data yang salah diprediksi }}{\text { jumlah data }} \times 100 \% \\
=\frac{1}{12} \times 100 \% \\
=8,33 \%
\end{gathered}
$$

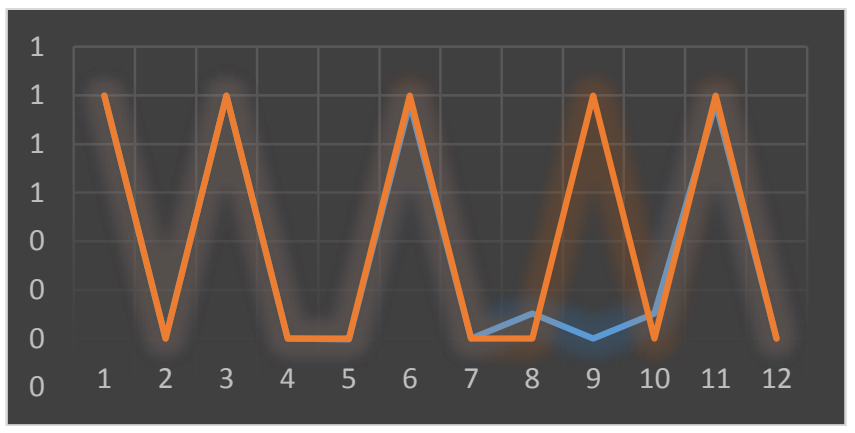

Gambar 5 : Perbandingan Hasil Prediksi Kualitas Air PDAM Kota Palu

Peramalan ini menggunakan JST terbaik dengan rancangan arsitektur neuron 12-1 yang didapatkan pada trial and error di pelatihan data yaitu learning rate 0,5 momentum constant 0,1 fungsi aktivasi logsig untuk hidden layer dan purelin untuk output layer. Setelah disimulasikan maka didapatkan hasil JST yang merupakan prediksi kualitas air bersih periode 2016.

\subsection{Pembahasan}

Data dalam penelitian ini adalah data kualitas air bersih berdasarkan parameter kualitas air bersih yaitu Bau, warna, kekeruhan, rasa, suhu, bakteri E Coli, pH, dan sisa chlor. Proses prediksi kualitas air bersih PDAM Kota Palu diawali dengan proses training dimana proses tersebut merupakan proses pembelajaran sistem agar sistem dapat mengklasifikasikan kualitas air bersih berdasarkan parameternya. Dari proses training dilanjutkan dengan testing data dimana pada tahapan testing sistem mulai melakukan proses prediksi kualitas air bersih untuk tahun 2016. Hasil penelitian menunjukan 12 data yang ditesting menggunakan backpropagation dan telah menghasilkan 12 hasil prediksi untuk periode tahun 2016 untuk kualitas air bersih. Keakurasian prediksi dari bulan januari - 
desember adalah $91,67 \%$ yang sesuai dengan data target dan $8,33 \%$ yang tidak sesuai dengan data target .

\section{KESIMPULAN}

Berdasarkan hasil dan pembahasan yang telah dilakukan, dapat ditarik beberapa kesimpulan sebagai berikut :

1. Hasil prediksi kualitas air bersih di PDAM Kota Palu adalah januari = 1 (tidak bersih), februari $=0$ (bersih), maret $=1$ (tidak bersih), april $=0$ (bersih), mei $=0$ (bersih), juni $=1$ (bersih), juli $=$ 0 (bersih), agustus $=0$ (bersih), september $=0$ (bersih), oktober $=0$ (bersih), november $=1$ (tidak bersih), dan desember $=0$ (bersih).

2. Proses prediksi JST yang dilakukan terhadap 48 data yang masing-masing di bagi menjadi 36 data pelatihan dan 12 data pengujian untuk prediksi kualitas air bersih menghasilkan sistem yang dapat bekerja dengan baik dan Tingkat akurasi backpropagation pada penelitian ini mengenali $91,67 \%$ data baru sesuai target dan $8,33 \%$ data baru yang berbeda dengan target.

\section{DAFTAR PUSTAKA}

[1]. Hermawan, A., 2006, Jaringan Syaraf Tiruan teori dan aplikasi, Yogyakarta.

[2]. Pasal 5 BAB I Undang-Undang Republik Indonesia Nomor 7 Tahun 2004 tentang Negara Menjamin Hak Setiap Orang Untuk Mendapatkan Air.

[3]. Puspitaningrum, D., 2006, Pengantar Jaringan Saraf Tiruan, Penerbit Andi, Jogjakarta.

[4]. Hsu, C, W., Lin, C, J., 2004, A Comparison Of MethodsFor Multi-Class Support Vector Machines, IEEE Transactions On Neural Networks, USA.

[5]. Sembiring, K., 2007, Tutorial Support Vector Machine Bahasa Indonesia, Sekolah Teknik Elektro dan Informatika, Institut Teknologi Bandung. 